WISDOM AND CREATIVITY IN OLD AGE:

LESSONS FROM THE IMPRESSIONISTS

\author{
David W. Galenson \\ Working Paper 13190 \\ http://www.nber.org/papers/w13190 \\ NATIONAL BUREAU OF ECONOMIC RESEARCH \\ 1050 Massachusetts Avenue \\ Cambridge, MA 02138 \\ June 2007
}

The views expressed herein are those of the author(s) and do not necessarily reflect the views of the National Bureau of Economic Research.

(C) 2007 by David W. Galenson. All rights reserved. Short sections of text, not to exceed two paragraphs, may be quoted without explicit permission provided that full credit, including $\odot$ notice, is given to the source. 
Wisdom and Creativity in Old Age: Lessons from the Impressionists

David W. Galenson

NBER Working Paper No. 13190

June 2007

JEL No. J01

\begin{abstract}
Psychologists have not considered wisdom and creativity to be closely associated. This reflects their failure to recognize that creativity is not exclusively the result of bold discoveries by young conceptual innovators. Important advances can equally be made by older, experimental innovators. Yet we have had no examination of why some experimental artists have remained creative much later in their lives than others. Considering the major artists who worked together during the first decade of Impressionism, this paper compares the attitudes and practices of two important experimental innovators who made significant contributions after the age of 50 with two of their colleagues whose creativity failed to persist past 50. Unlike Pissarro and Renoir, who reacted to adversity in mid-career by attempting to emulate the methods of conceptual artists, Cézanne and Monet adopted elements of other artists' approaches while maintaining their own experimental methods and goals. For both Cézanne and Monet, recognizing how they themselves learned was a key to turning experience into wisdom. Their greatness in old age appears to have been a product of their understanding that although the improvement in their art might be painstaking and slow, over long periods its cumulative effect could be very great.

David W. Galenson

Department of Economics

University of Chicago

1126 East 59th Street

Chicago, IL 60637

and NBER

galenson@uchicago.edu
\end{abstract}




\section{The Question}

Published in 1953, Harry Lehman's Age and Achievement remains the most ambitious empirical study of the relationship between age and creativity ever undertaken by a psychologist. Based on his analysis of the life spans of important practitioners of scores of different activities, Lehman summarized his results by observing that "it remains clear that the genius does not function equally well throughout the years of adulthood. Superior creativity rises relatively rapidly to a maximum which occurs usually in the thirties and then falls off slowly.” Old age does have some positive attributes: "the old usually possess greater wisdom and erudition. These are invaluable assets." Yet these invaluable assets do not lead to creativity: "But when a situation requires a new way of looking at things, the acquisition of new techniques or even new vocabularies, the old seem stereotyped and rigid. To learn the new they often have to unlearn

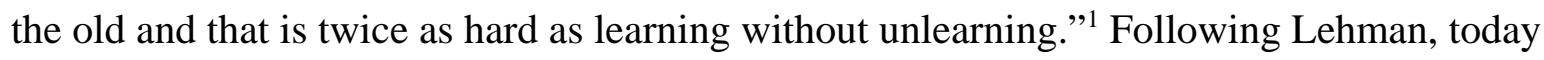
psychologists continue to believe that practitioners of most intellectual activities reach their creative peaks relatively early in their adult lives. ${ }^{2}$ Wisdom and creativity are concepts that psychologists do not generally consider to be closely associated. Robert Sternberg, for example, recently explained that "the kinds of thinking required to be creative and wise are different.” For Sternberg, innovators are impetuous rather than deliberate: "Creative thinking is often brash whereas wise thinking is balanced.”3

These psychologists have failed to recognize the variety of creativity. It is true that bold and brash leaps into the unknown are an important source of innovations. But there is also another, very different form of creativity, in which important new discoveries are the cumulative product of gradual and incremental experimentation. Ignoring this latter type of creativity has 
caused a misunderstanding of the diversity of creative life cycles, for whereas the first type of innovation is usually made early in an innovator's career, the second type is generally made by older individuals. It is within this second type of innovation that we must look for the link between wisdom and creativity.

Recent studies of individual innovators in the arts have revealed numerous instances in which great artists have made their most important contributions late in their lives. ${ }^{4}$ A striking example appears in a study of the greatest women artists of the twentieth century, in the career of the sculptor Louise Bourgeois. The period from which Bourgeois’ work is most likely to be illustrated in textbooks of art history is the first half of her $80 \mathrm{~s}^{5}{ }^{5}$ In view of the fact that art historians judge that the most important work of her career was made in her ninth decade, it is perhaps not surprising that Bourgeois believes that artists improve with age. In 1995, when she was 84, Bourgeois told an interviewer that she could not have made one of her recent works earlier in her career, because "I was not sophisticated enough then. You know, artists improve. I mean, we are supposed to be better today than we were twenty years ago. Otherwise, what's the use of working?” When the interviewer inquired about the source of the improvement, Bourgeois explained that "you become better in every way, morally, intellectually, physically no, not physically. You become better, which is really the Chinese philosophy - the wisdom of the elders." 6

Earlier studies have shown that artists who make important contributions late in their lives are almost invariably experimental innovators, whose uncertainty about their goals causes them to proceed more gradually and cautiously than their conceptual counterparts. ${ }^{7}$ Bourgeois is an archetypal example of an experimental artist. She does not plan her forms in advance, but 
finds them in the course of working: "The finished work is often a stranger to, and sometimes very much at odds with what the artist felt or wished to express when he began.” She is never satisfied that a work or a problem has been fully resolved: “That’s why I keep going. The resolution never appears; it’s like a mirage.” Making art is a struggle: “I have no fun at all - in fact everything I do is a battlefield, a fight to the finish.” Progress comes from adversity: "My style, the way I work comes from all the failures, all the temptations I have resisted, all the fun I didn't have, all the regrets."

Yet although Bourgeois' attitudes are typical of the class of experimental innovators, her life cycle is not. While it is now clear that experimental innovators tend to make their greatest contributions later in their lives then their conceptual counterparts, most nonetheless make their most important contributions considerably earlier than Bourgeois. It is consequently of interest to ask what causes this variation: why do some experimental innovators continue to develop their art much longer than others?

A complete answer to this question is not possible, for it would require complete knowledge of the circumstances and motivations of all the relevant individuals. Yet it is possible that careful comparative studies of small numbers of important innovators can begin to give us some clues as to why some creative individuals persevere, and succeed, for longer periods than others. This paper will perform one such study.

The importance of this investigation is increased by the fact that the phenomenon of interest is not unique to the arts, but appears to be common to all intellectual activities. Studies of scholars have shown that a number of important figures have made their greatest contributions late in their lives, and these individuals appear to be those who follow the inductive methods that 
are characteristic of experimental innovators. ${ }^{9}$ Understanding why some experimental artists remain creative longer than others may therefore help us to increase the productivity not only of artists, but of innovators in all intellectual activities.

\section{$\underline{\text { Patterns }}$}

This paper will examine the careers of five important experimental painters who were central figures in the advanced art world of the late nineteenth century. ${ }^{10}$ These five - Cézanne, Degas, Monet, Pissarro, and Renoir - were the five greatest artists who exhibited at the epochmaking Impressionist exhibition of $1874 .{ }^{11}$ All were born within an 11-year span, and all lived beyond the age of 65 . They were friends as well as professional colleagues, and shared a common artistic milieu for much of their lives.

The basis for a systematic assessment of the creativity of each of the five artists over the course of their careers is provided by a survey of the illustrations of their work that appear in 43 textbooks of art history published in English since $1970 .{ }^{12}$ Table 1 shows that the five are prominently represented in these books, as all have an average of more than one illustration per book.

Table 2 presents the distribution of the illustrations of each artist's work by the age at which the artist executed the works. There are pronounced differences in these distributions across artists. One way to highlight these differences is to consider the most important contributions made by these five artists early and late in their lives. In total, Table 2 contains ten entries of 15 illustrations or more for these five artists below the age of 50. Four of these ten entries are for Renoir and Pissarro. In contrast, there are five entries of at least 15 illustrations for the five artists after the age of 50, but none of these five is for either Renoir or Pissarro. 
Table 2 shows that Cézanne’s art grew steadily in importance over time, with his greatest work in his last years; his largest entry in the table is for his 60s, the final decade of his life. Monet was greatest early, in his 20s and 30s, but he also made important contributions in both his 50s and his 80s. Degas was at his greatest from his 30s through his 50s. Renoir and Pissarro were both greatest before the age of 50, and produced little of importance thereafter.

The quantitative evidence suggests that the most pronounced cases of creativity persisting into old age among these five artists are those of Cézanne and Monet, and that the clearest cases of failure of creativity to persist past 50 are those of Renoir and Pissarro. These are the contrasting careers that will be of greatest interest for this inquiry, and each of the four will be considered individually.

\section{Careers}

Monet was the first of the Impressionists to gain widespread recognition. The most celebrated early innovations of the Impressionists were in landscape painting, and these first appeared in paintings Monet and Renoir did in 1869 at a popular bathing place on the Seine near Paris, in which they created novel effects to portray the reflection of light on the water. Kenneth Clark observed that their new technique was so powerful "that it not only captivated sympathetic spirits like Sisley and Pissarro, but imposed itself on painters to whom it was quite alien,” including Manet, Gauguin, and van Gogh. ${ }^{13}$ The 1870s became the triumphant decade of Impressionism among the artists in Paris’ advanced art world, and Monet was recognized as the movement's informal leader.

The 1880s brought adversity. Monet and the other Impressionist landscape painters, including Renoir and Pissarro, began to question their ability to make further developments in 
their art. At the same time, younger painters began to create new styles that built on Impressionism, but that rejected many of its fundamental tenets. Notable among these young artists was Georges Seurat, who became the leader of a new movement that intended to replace the unsystematic approach of the Impressionists with scientific method, based on rules derived from scientific experiments on the perception of color. Advocates of the new movement, which was soon named Neo-Impressionism, not only praised Seurat and his followers for their rigorous technique and the firm scientific basis of their art, but criticized Monet and the other Impressionists for their haphazard and instinctive approach. ${ }^{14}$

In 1888, Monet began to make the first of what would come to be known as his series paintings - views of a single subject, seen at different times of day, and in different seasons, under different conditions of light and atmosphere. ${ }^{15}$ From then through the mid-1890s, he made serial studies of specific motifs that included wheat stacks near his home in Giverny, a row of poplar trees along the Epte River, the façade of Rouen cathedral, a view of the Seine near Giverny, and the coast of Normandy. ${ }^{16}$ Arthur Danto has contended that these series paintings were Monet's response to Seurat's challenge:

Seurat was young, brilliant, and charismatic, and in the art world of Paris in the late 1880s, his innovation, Pointillism, was perceived as a challenge to the premises of Impressionism, and in particular to Monet as the embodiment of Impressionist ideals. Pointillism was "scientific," grounded in the latest color theories... Impressionism was redeemable only if it could meet the scientific challenge of Pointillism by showing itself to be just as "scientific." And that, in my view, is at least part of what the series paintings undertook to do... Monet would have had every reason to think of himself as behaving scientifically in noting "the effects of light... on appearance and color." ${ }^{\text {17 }}$

The series paintings account for the increase in Monet’s illustrations in Table 2 during 
his 50s: the textbooks include 19 illustrations of 11 different paintings of Rouen Cathedral that he painted in 1894, and five illustrations of four paintings of wheat stacks that he painted in 1891. Monet's paintings of this period are considered innovative for their pioneering use of serial imagery, which would later become central to the work of Andy Warhol, Frank Stella, and many other major artists of the 1960 s and beyond. ${ }^{18}$

Monet's final large entry in Table 2, for the last decade of his life, represents yet another phase of his career. After 1900, his art was dominated by paintings of the water lilies in the pond he had constructed in the garden of his house in Giverny. The textbooks surveyed for this study contain 29 illustrations of 23 paintings of the water lilies he executed between 1900 and his death in 1926. These late paintings received little attention during Monet’s lifetime: although Monet had come to be a revered figure, after 1900 he was known for an art that had been superseded by the revolutionary innovations of much younger artists, including notably the Fauves and the Cubists. Picasso, the leading Cubist, specifically intended his art to be a rejection of Impressionism, and he ridiculed Monet’s large paintings of water lilies by comparing them to a decoration he had once seen in a brothel. ${ }^{19}$ Yet the water lilies were rediscovered during the 1950s, when a number of artists and critics identified them as direct antecedents of the paintings of Jackson Pollock, Mark Rothko, Sam Francis, and other Abstract Expressionists. ${ }^{20}$ Monet's late paintings were considered to have anticipated key innovations of the abstract artists of the 1950s in their all-over compositions, which lacked any central point of interest, in the large scale that allowed the viewer to be enveloped by the painted image, and in the spontaneous and expressive use of color that was largely freed from representation.

Pissarro, a decade older than Monet, also made his greatest contribution during the 
heyday of Impressionism in the 1870s. And like Monet, Pissarro’s career was profoundly affected by the crisis of Impressionism during the 1880s, and by the challenge of Seurat's NeoImpressionism. Yet Pissarro's reaction to Seurat was radically different from that of Monet, and it is possible that this was responsible for the sharp decline in Pissarro's creativity during the remainder of his career.

Pissarro was a central figure in the Impressionist movement during the 1870s. This entailed considerable personal hardship, for recognition of the importance of the new technique by critics and collectors lagged behind its influence on other painters. ${ }^{21}$ With Monet, Pissarro led the effort to organize the first Impressionist group exhibition in 1874, and he was the only one to remain loyal to the new institution throughout its history, as he was the only artist to exhibit in all of its eight manifestations. ${ }^{22}$ Artistically, the decade of the 1870 s was a time of exciting experimentation: looking back years later, Pissarro reflected that "though I was full of ardor, I did not have the slightest idea, even at the age of forty, of the profound aspect of the movement which we pursued instinctively. It was in the air." ${ }^{23}$

Yet Pissarro had the basic uncertainty of a true experimental artist, and he was never free of fears and doubts. In 1883, for example, he assured his son Lucien that "I will calmly tread the path I have taken,” even though “At bottom, I have only a vague sense of its rightness or wrongness." ${ }^{24}$ Pissarro met Seurat in 1885, and he almost immediately became a convert to the younger artist’s Neo-Impressionism. ${ }^{25}$ The next year, Pissarro was already explaining to his dealer, Paul Durand-Ruel, that Seurat's “modern synthesis of methods based on science” allowed the artist to plan and execute his paintings confidently and systematically: "As far as execution is concerned, we regard it as of little importance: art, as we see it, does not reside in the 
execution.”26 Monet was stung by his friend's defection, and criticized Pissarro’s adoption of what he called “chemical” techniques, but Pissarro responded by calling his old colleagues "romantic” Impressionists, who could not appreciate the progressive nature of the new “scientific” Impressionism because they feared it would surpass them. ${ }^{27}$ In 1887, Pissarro predicted that the Neo-Impressionists would replace the Impressionists just as the Impressionists had earlier replaced academic art: "Once our paintings are hung somewhere they will have an effect like our early canvases had on official art.”28

Unfortunately, however, Pissarro soon found Neo-Impressionism confining and limiting. In 1888, he wrote to Lucien that the technique’s small touches of color frustrated him: "How can one combine the purity and simplicity of the dot with the fullness, suppleness, liberty, spontaneity and freshness of sensation postulated by our impressionist art? This is the question which preoccupies me, for the dot is meager, lacking in body, diaphanous, more monotonous than simple, even in the Seurats."29 The next year, he told Lucien that he was "looking for some substitute for the dot; so far I have not found what I want, the actual execution does not seem to me to be rapid enough and does not follow sensation with enough inevitability."30 In 1891, after Seurat's premature death, Pissarro confessed to Lucien that "I believe you are right, pointillism is finished.”31 Several years later, looking back on this episode, Pissarro explained this failure to a fellow artist:

Having tried this theory for four years and having now abandoned it, not without painful and obstinate struggles to regain what I had lost and not to lose what I had learned, I can no longer consider myself one of the neo-impressionists who abandon movement and life for a diametrically opposed aesthetic which, perhaps, is the right thing for the man with the right temperament but is not right for me, anxious as I am to avoid all narrow, so-called scientific theories. Having found after many attempts... that it was 
impossible to be true to my sensations and consequently to render life and movement, impossible to be faithful to the so random and so admirable effects of nature, impossible to give an individual character to my drawing, I had to give it up. ${ }^{32}$

Renoir was also a core member of the Impressionists during the 1870s, as he frequently painted beside Monet, and exhibited in the first three Impressionist exhibitions. But like Pissarro, he reacted to the crisis of the 1880s by renouncing Impressionism, though in a very different way.

On a trip to Italy in 1881, Renoir was struck by the beauty of the painting of Raphael: "I have seen the Raphaels at Rome. They are very beautiful and I ought to have seen them long ago. They are full of knowledge and wisdom... I prefer Ingres in oil painting but the simplicity and grandeur of the frescoes is admirable.”33 Interestingly, seeing the work of Raphael reminded Renoir of the art of Ingres, one of the leading academic artists in early nineteenth-century France. This heightened awareness probably contributed to Renoir's feeling that “about $1883 . .$. I had reached the end of Impressionism and came to the conclusion that I did not know how to paint or draw. In a word, I had reached an impasse."34 He realized that he had to reject the Impressionist emphasis on direct observation of nature: "When the artist paints directly from nature he reaches a point when he no longer composes but looks wholly for the momentary effects of light. That soon leads to monotony.”35

Renoir decided to return to a more traditional and classical art, that would value draftsmanship and conception over color and spontaneity. By 1886, he was firmly in the grip of what a biographer called "Ingres worship,” and after a visit to his studio his friend and fellow painter Berthe Morisot remarked in her diary on the divergence of his practice from that of his Impressionist friends: "How interesting it would be if all these preliminary studies for a painting 
could be shown to the general public which still thinks that the Impressionists work casually." ${ }^{36}$ Renoir appears to have followed this practice for the remainder of his long career, as the painter Albert André reported that Renoir would prepare for complicated compositions by making small preliminary oil sketches, as "a sort of practice for the definitive work. When it is fixed in his mind, he next draws his composition in sanguine [red chalk], and traces it on to his canvas.”37 In view of Renoir’s abandonment of Impressionism and his embrace of classical methods, it is perhaps not surprising that he contended that artistic practices were timeless. When his dealer and friend Ambrose Vollard asked Renoir late in his life if he believed there had been progress in painting, he responded: "No, I cannot see any. No progress in ideas, nor any in technique, either.” Remarkably, he denied that even the colors available to modern artists had been improved: “On the whole, the modern palette is the same one used by the artists of Pompeii... down to Poussin, Corot and Cézanne; I mean that it has not been enriched... tones have been added, but we could easily do without them.”38

Cézanne was a latecomer to Impressionism. In 1872, however, he left his native Aix-enProvence to live near Pissarro in Pontoise, and during the next few years he spent a considerable amount of time working with Pissarro to learn the new techniques. He was deeply grateful to the older artist for teaching him to base his art on the study of nature, and both his palette and his application of paint were transformed during his time in Pontoise; thus years later Cézanne recalled that Pissarro "was like a father to me. You could always ask him questions; he was something like the good God.”39 Cézanne never fully adopted the methods of the Impressionists, because he did not share their goal of portraying the momentary effects of light and atmosphere, and he was more committed than they to creating solid and timeless images. But what Roger Fry 
called his apprenticeship to Pissarro in Pontoise was the key turning point in Cézanne's art, that allowed him to begin the quest for a new style that would occupy the rest of his life. ${ }^{40}$

Our knowledge of Cézanne’s career after the mid-1870s is clouded by considerable uncertainty. More than the other Impressionists, as he grew older he became reclusive: he spent more and more time in his native Aix, and even on visits to Paris he appears to have avoided contact with other artists. The evolution of his style can be traced through his paintings, but even here there is much uncertainty about timing, because he sold few works, and rarely dated his paintings. He appears to have worked on many of his paintings over extended periods, for his perennial dissatisfaction with his achievement appears to have led him to feel that even individual works were rarely definitely finished.

Cézanne exhibited in the Impressionist group shows in 1874 and 1877, but there were no further exhibitions of his work in Paris until 1895, when Vollard presented his first one-man show. His reclusiveness helped make him a mysterious and even legendary figure in Paris’ art world, as for example in 1894 the critic Gustave Geffroy wrote that Cézanne "might be described as a person at once unknown and famous, having only rare contact with the public yet considered influential by the restless and the seekers in the field of painting... All the littleknown facts about his life, his almost secret productivity, the rare canvases which seem to follow none of the accepted rules of publicity, all these give him a kind of strange renown, already distant; a mystery surrounds his person and his work." ${ }^{41}$

The power and novelty of the paintings in Vollard's 1895 exhibition surprised even Cézanne’s old friends. Pissarro wrote to Lucien that there were “exquisite things, still lifes of irreproachable perfection, others much worked on and yet of even greater beauty.” Pissarro 
reported that Renoir, Degas, and Monet shared his enthusiasm; Degas and Monet bought works from the show, as did Pissarro, and Degas and Renoir actually drew straws to settle their dispute over who would buy one still life. ${ }^{42}$ The exhibition increased Cézanne’s reputation in Paris, and during the following decade several younger painters made trips to Aix to meet him. Notable among these was Emile Bernard, who later published an account of a month he had spent with Cézanne in 1904. One of the more dramatic incidents he described referred to Honoré de Balzac's story The Unknown Masterpiece, in which a fictional $17^{\text {th }}$-century master named Frenhofer labored for years attempting to paint a single perfect work of art, the portrait of a beautiful woman. When he failed, in frustration he destroyed the painting and killed himself. Bernard recalled that one evening he had spoken to Cézanne of the mythic Frenhofer: "He got up from the table, stood before me, and, striking his chest with his index finger, he admitted wordlessly by this repeated gesture that he was the very character in the novel. He was so moved by this feeling that tears filled his eyes."43

In Cézanne’s letters, and accounts of his conversations, he used a distinctive vocabulary to describe his artistic practice. A famous element of this was his stated goal of "realization," the meaning of which has long been debated by art historians because of its ambiguity - an ambiguity that inevitably resulted from Cézanne’s own uncertainty, since this was a visual goal that he could not preconceive. Less remarked is his recurring use of language that portrayed him as a student or scholar, as he consistently used such words as study, education, and understanding to describe what he did in the process of working. Examples abound. In a letter to Bernard in 1904, he advised the younger painter: "I must always come back to this: painters must devote themselves entirely to the study of nature and try to produce pictures which will be 
an education." ${ }^{\text {4 }}$ The same year, he urged another young painter to be patient: "The understanding of the model and its realization is sometimes very slow in coming for the artist.” And perhaps most striking of all in this language of study and eventual understanding is a reference to an outcome of the process, in an assurance he made to Bernard late in 1905, a year before his death: "I owe you the truth about painting and shall tell it to you." 45

In Cézanne’s opinion artistic progress could come only through the study of nature, and the nature he came to prefer ever more strongly was that of his native Provence. He returned again and again to the same motifs. Thus for example the textbooks surveyed for this study contain a total of 40 illustrations of 12 different paintings Cézanne made of his beloved Mont Sainte-Victoire, the earliest of which he executed in 1885, the latest in 1906, the year of his death. One of Cézanne’s most important late innovations stemmed directly from his careful inspection of the subjects of his paintings. Specifically, his meticulous attention to vision made him consider the effect of the inevitable slight changes in the artist's point of view that occurred in the process of working, as he looked back and forth from his canvas to the motif. The problem these changes posed to creating a discrete image became a growing source of concern to him over time, and they gave rise to the celebrated inconsistencies in the contours of many objects in his late works that resulted from his explicit incorporation into a single painting of several different viewpoints. ${ }^{46}$ A month before his death, he wrote to his son of his preoccupation: "Here on the bank of the river the motifs multiply, the same subject seen from a different angle offers subject for study of the most powerful interest and so varied that I think I could occupy myself for months without changing place, by turning now more to the right, now more to the left." ${ }^{\text {47 }}$ The small numbers of marginal changes in viewpoint that Cézanne 
represented in individual paintings were seized on and multiplied by the young conceptual painters Picasso and Braque, whose many extreme changes in viewpoint created the faceting of objects that was a central feature of early analytical Cubism.

\section{$\underline{\text { Attitudes }}$}

Cézanne and Monet expressed a number of beliefs that appear related to their extended creativity. Both artists were consistently dissatisfied with their work, and were frustrated by their inability to achieve their goals. In 1888, Monet wrote to a fellow painter that “I'm never finished with my paintings; the further I get, the more I seek the impossible and the more powerless I feel." ${ }^{\text {48 }}$ In 1890, he wrote to his friend Gustave Geffroy that "I am profoundly disgusted with painting. It really is a continual torture!”49 While working on the series of paintings of Rouen cathedral in 1893, he complained to his wife, "What's the good of working when I don’t get to the end of anything?"50 Cézanne repeatedly returned to the theme of how slowly and painfully he advanced, as in a letter to Bernard in 1904: "I progress very slowly, for nature reveals herself to me in very complex ways, and the progress needed is endless." ${ }^{\text {51 }}$ The year before, the 64-year-old artist had written plaintively to Vollard: "I have made some progress. Why so late and with such difficulty? Is art really a priesthood that demands the pure in heart who must belong to it entirely?"52

Both artists spent their entire careers pursuing a single elusive and imprecise visual goal. Monet tried to describe his goal to Geffroy in 1890: "the further I get, the more I see that a lot of work has to be done in order to render what I'm looking for: 'instantaneity,' the 'envelope' above all, the same light spread over everything... I'm increasingly obsessed by the need to render what I experience.”53 Just months before his death, Monet could summarize his 
achievement in a sentence: "finally the only merit I have is to have painted directly from nature with the aim of conveying my impressions in front of the most fugitive effects. ${ }^{, 54}$ In 1905, Cézanne complained that "My age and health will never allow me to realize my dream of art that I have been pursuing all my life." ${ }^{55}$ A month before his death he wondered, "Will I ever attain the end for which I have striven so much and so long?"56

As they grew older, both Cézanne and Monet separated themselves from most other artists, not only geographically but also intellectually. This appears to have been a conscious act, in order to allow themselves to concentrate on their own goals without being distracted or diverted from their chosen course. In 1889, Cézanne explained to the organizer of an exhibition in Brussels his reluctance to exhibit his work: "As the many studies to which I have dedicated myself have given me only negative results, and as I am afraid of only too justified criticism, I had resolved to work in silence until the day when I should feel myself able to defend theoretically the result of my attempts. ${ }^{, 57}$ Late in his life Monet increasingly secluded himself in Giverny, and often declined invitations to travel by citing the need to work, as for example in 1918 when he told his dealer "never have I been less keen to take any time off from my painting; I haven't many years left ahead of me and I must devote all my time to painting, in the hope of achieving something worthwhile in the end." ${ }^{58}$ Even Cézanne was aware of Monet’s reputation for discouraging visitors, as in 1903 he asked a younger painter to give his regards to his old friend: "If you meet the master whom we both admire, remember me to him. He does not, I believe, much like being bothered, but in view of the sincerity he may relax a little."59 Interestingly, Roger Shattuck drew a parallel between Monet's relationship to his garden in Giverny and that of Cézanne to the landscape of Provence, remarking that "The genius of the 
place [Monet] had made abetted his own genius. This late development in Monet's work parallels that of Cézanne’s last years (1895-1906), during which he studied a few highly familiar sites around Aix-en-Provence. Aix provided his garden. Both artists settled deeper into the role... of the artist as stubborn peasant, scorning public taste, dismissing criticism and theory, cultivating his garden.”60

Both artists were inductive and empirical in their approach to art: they shared an unswerving belief in the necessity of painting constantly, and proceeding consistently by trial and error. Early in his career, Monet assured his friend and fellow painter Frédéric Bazille that “It's on the strength of observation and reflection that one finds a way. So, we must dig and delve unceasingly.”1 Three decades later, Monet was still reminding himself to be patient: “The essential thing is to avoid the urge to do it all too quickly, try, try again, and get it right.”62 Cézanne repeatedly turned theoretical discussions of art back to the need to learn by working: “The artist must be a laborer in his art... He becomes a painter through the very qualities of painting itself.”63 He devoted himself entirely to his work, as two months before his death he confessed to his son that "I live a little as if in a void. Painting is what means most to me." Just a week before his death, he wrote to his son that he had become weak, but "I must carry on. I simply must produce after nature.”64 Both artists had a deep mistrust of theoretical approaches to art. Near the end of his life, Monet told a journalist "I’ve always had a horror of theories.”65 Cézanne was no less an empiricist, as he wrote to a younger painter that there was little useful advice he could give him: "indeed one says more and perhaps better things about painting when facing the motif than when discussing purely speculative theories - in which as often as not one loses oneself.”66 
Finally, both Cézanne and Monet believed that, with constant application, gradual progress could be made over time. Cézanne wrote in 1904 that he believed that he was attaining greater realization every day, explaining that "Because, if the strong feeling for nature - and certainly I have that vividly - is the necessary basis for all artistic conception on which rests the grandeur and beauty of all future work, the knowledge of the means of expressing our emotion is no less essential, and is only to be acquired through very long experience.”67 Later the same year, he wrote to Bernard that "In order to make progress, there is only nature, and the eye is trained through contact with her." ${ }^{\text {"68 }}$ The next year, he told Bernard that "It is ... very painful to have to state that the improvement produced in the comprehension of nature from the point of view of the picture and the development of the means of expression is accompanied by old age and a weakening of the body." Yet he believed that his practice yielded results: "Time and reflection... modify little by little our vision, and at last comprehension comes to us.”69 In 1909, Monet similarly declared that he believed that he had become a better artist over time: "I have half a century of experience and soon I shall have passed my sixty-ninth year, but my sensitivity, far from diminishing, has been sharpened with age, which holds no fears for me as long as unbroken communication with the outside world continues to fuel my curiosity, so long as my hand remains a ready and faithful interpreter of my perception.”70

\section{$\underline{\text { Lessons }}$}

A large body of research has now demonstrated that artists who are at their most creative late in life are almost invariably experimental innovators. Yet what has not been considered is the source of variation in the life cycles of these experimentalists. Specifically, there are substantial differences in the ages at which experimental artists are most creative. Why do some 
experimentalists remain creative much longer than others? As noted earlier, Louise Bourgeois, who has remained creative throughout her very long life, has claimed that artists improve with age, and has attributed this to "the wisdom of the elders." The problem is more complex, however; why do some artists gain wisdom, while others do not?

This study considered the careers of five Impressionist painters, all experimental artists who shared many attitudes toward art and who worked under similar conditions for much of their lives. A quantitative survey revealed that two of these - Monet and Cézanne - remained creative throughout their lives, whereas two - Renoir and Pissarro - declined sharply in creativity after the age of 50. The study went on to examine the causes of these sharply differing career patterns, in the form of differences in behavior and attitudes among these four artists. These cases provide us with lessons on how and why some artists remained creative much longer than others.

Their vague goals and trial-and-error methods make virtually all ambitious experimental artists prone to frustration at the slow development of their work, and this is almost always compounded by frustration at the lack of appreciation of their art by others. How the artists respond to their frustration has a great impact on the course of their creativity over time.

Pissarro and Renoir reacted to their frustration by effectively trying to become conceptual artists. Both of these attempts ended badly. Pissarro, the more self-critical of the two, eventually recognized that his subtle and nuanced experimental view of the world could not be transformed into the more mechanical and simplified conceptual approach of Seurat and his followers. Renoir appears never to have understood that he could make only mediocre art using the classical conceptual approach he adopted, and his paintings for the remainder of this career 
served primarily as decorations for the homes of wealthy admirers. During the 1880s, both Pissarro and Renoir began to make preparatory drawings for paintings that were essentially studio compositions - a fundamentally conceptual practice, and a basic departure from the Impressionists' experimental conviction that a painting should be a direct record of the artist's perception of the motif. ${ }^{71}$ In contrast, neither Monet nor Cézanne ever did this during this period, or after. ${ }^{72}$ Neither Pissarro nor Renoir made any significant contribution to art using conceptual methods.

Monet and Cézanne reacted very differently to their frustration. At different stages, both managed to learn from others, but without fully adopting the methods or goals of the other artists. Instead, both adapted elements of other artists' approaches to their own techniques, thus adding to their artistic vocabularies while retaining their basic strengths. Cézanne learned from Pissarro the value of nature as an object of study, just as he learned the power of the Impressionists’ novel approach to color. Yet even from the beginning of his apprenticeship, Cézanne recognized that the Impressionists’ goal of portraying transitory and ephemeral visual effects was not suited to his interest in timelessness and solidity, and the greatness of his late work came from the development of his remarkable synthesis of the Impressionists’ palette with his own novel structural innovations, including his distinctive constructive brushstroke and the use of multiple viewpoints within a single composition. Monet reacted to the challenge of Seurat, and the younger artist's celebrated scientific approach, by creating his own version of scientific art. The series paintings of the 1890s not only continued Monet's previous concern with the instantaneous effects of light and atmosphere, but highlighted it, making those effects the primary subject of the studies. In this way Monet transformed a visual method that had been 
criticized as incoherent and haphazard into one that was clearly systematic and methodical. It should be emphasized that although the motivation for the series paintings may have been the challenge of Seurat's scientific approach, Monet did not in any way attempt to copy Seurat's conceptual method. There was nothing mechanical about this enterprise. Each series is characterized by a number of minor but clearly perceptible differences among the individual paintings. Considering for example the views of Rouen cathedral, the sizes of the canvases differ, the angle from which the facade is seen differs, and the compositions differ - more of the width of the facade appears in some paintings than in others. These differences heighten the viewer's awareness of the artist's careful observation of the motif, but they do not interfere with the obvious unity of the works within the series. George Heard Hamilton's judgment that the Rouen cathedral series was a "climax of Impressionism” stressed both the perceptual basis of the paintings and the cumulative nature of their achievement, as he concluded that "Upon the basis of a technique painstakingly developed through thirty years of experimentation and directed toward the depiction of separate, isolated, unrelated instants in the outer world of positivist, physical causality... Monet erected a new kind of painting which reveals the nature of perception rather than the nature of the thing perceived."73 Later, Monet extended his careful examination of his subject even further, going beyond the discrete series paintings into the more numerous and much larger canvases of the water lilies in Giverny, which served to present an effectively continuous and endless view of nature. Again recognizing the cumulative nature of Monet's art, in 1952 the painter André Masson called the Musée de l’ Orangerie, where a sequence of Monet’s enormous late paintings of water lilies were installed in 1927, the "Sistine Chapel of Impressionism.”74 As he aged, Monet changed his art gradually, as he discovered new ways to 
increase the intensity with which he explored his fundamental concerns.

Conceptual artists not only offer greater clarity of intent, but they can change more quickly than experimentalists: thus Seurat could shift from a concern with color to studies of the use of line, and other young conceptual painters of the 1880s and beyond could change styles rapidly. Monet and Cézanne both understood that their art was suited to gradual evolution rather than rapid change. As they grew older, their progressive withdrawal from the debates of the advanced art world, underscored by their choices to live and work outside Paris and away from other artists, were symptomatic of their desire to pursue their own goals without distraction or discouragement from others. The 50-year-old Cézanne’s explanation that he had vowed to work in silence is consistent with his realization that he could advance his art only by working in his own way. Both Cézanne and Monet realized that once they had arrived at their mature formulations of their artistic goals, they would not benefit from trying to compete with more protean conceptual artists on those artists' own terms, and they never attempted to do so.

Remaining dedicated to their personal goals required extraordinary perseverence and dedication. Both Cézanne and Monet spent most of their adult lives in an art world whose intellectual atmosphere was basically hostile to their goals, as from the 1880s on, from the NeoImpressionists and the Nabis to the Fauves, Cubists, and beyond, conceptual approaches to art dominated Paris' advanced movements. Yet neither artist gave in to the temptation to change his goals, or even to claim that his art was motivated by conceptual goals. Just a month before his death, Cézanne reasserted his belief in the primacy of perceptual motivations over conceptual concerns in a letter to the younger - conceptual - painter Bernard: "I believe in the logical development of everything we see and feel through the study of nature and turn my attention to 
technical questions later; for technical questions are for us only the simple means of making the public feel what we feel ourselves and of making ourselves understood."75 In a similar statement several decades later, Monet gently chided his old friend Georges Clemenceau for the latter's preoccupation with abstract philosophical speculation, arguing that his own concern with perception offered a more reliable path to understanding: "When one is on the level of concordant appearances, one cannot be very far from reality, or at least from what we can know of it. The only thing I have done is to look at what the universe showed me, in order to render witness to it by my brush. Is that not something? Your fault is to wish to reduce the world to your own measure, whereas, by increasing your knowledge of things, you would increase knowledge of yourselves."76

What both Cézanne and Monet understood from an early point in their careers was how they themselves learned. Both recognized that although other, conceptual artists could benefit from formulating and applying theories, they could not, for they were empiricists, who could learn best from their own experiments. This recognition appears to have been a key for both artists in turning experience into wisdom. Both used their dissatisfaction as a constant spur motivating them to improve their art, but both also recognized their progress. Their self-critical ability allowed them to separate successful experiments from failures, and this enabled both to make their trial-and-error methods the basis of an improvement in their art over time. This improvement might be painstaking and slow, but both understood that over long periods its cumulative effect could be very great.

This recognition is enormously important. We often tend implicitly to assume that radical innovations, in art and other intellectual activities, are necessarily the result of dramatic actions. 
But this is incorrect. Sudden leaps certainly can yield radical results: from Masaccio’s creation of a new visual space in the murals of Florence’s Brancacci Chapel to Picasso's declaration of a very different new pictorial space in Les Demoiselles d'Avignon, examples come readily to mind. Yet the late achievements of Cézanne and Monet are prime demonstrations of how radical innovations can equally be achieved through gradual and incremental procedures. Cézanne’s analytical views of Mont Sainte-Victoire and Monet's sweeping panoramas of the waterlilies in Giverny are among the most radical developments in Western art, and both of these bodies of work were the culmination of decades of experimentation. ${ }^{77}$ The successful realization of such extended campaigns is the triumph of great experimental innovators. There is little doubt that both Cézanne and Monet would have identified completely with a statement Louise Bourgeois made about her art: "I am a long-distance runner. It takes me years and years and years to produce what I do."78 


\section{$\underline{\text { Footnotes }}$}

I thank Robert Jensen and Joshua Kotin for discussions.

1. Harvey Lehman, Age and Achievement (Princeton: Princeton University Press, 1953), pp. 330-31.

2. E.g. see the summary discussion in R. K. Sawyer, Explaining Creativity (Oxford: Oxford University Press, 2006), pp. 159-63.

3. E.g. see Robert Sternberg, Wisdom, Intelligence, and Creativity Synthesized (Cambridge: Cambridge University Press, 2003), p. 158; also see pp. 180-81.

4. $\quad$ E.g. David Galenson, Artistic Capital (New York: Routledge, 2006), Chap. 11.

5. David Galenson, “The Two Life Cycles of Artistic Creativity,” Historically Speaking Vol. 8, No. 3 (January 2007), p. 29.

6. Louise Bourgeois, Destruction of the Father, Reconstruction of the Father (Cambridge: MIT Press, 1998), pp. 318-19.

7. David Galenson, Old Masters and Young Geniuses (Princeton: Princeton University Press, 2006).

8. Bourgeois, Destruction of the Father, pp. 66, 162, 169, 218.

9. Bruce Weinberg and David Galenson, “Creative Careers,” NBER Working Paper 11799 (2005); also see Richard Posner, Aging and Old Age (Chicago: University of Chicago Press, 1995), pp. 188-93.

10. On Impressionism as an experimental art, see David Galenson, Painting outside the Lines (Cambridge: Harvard University Press, 2001), pp. 80-91.

11. Galenson, Artistic Capital , pp. 6, 25.

12. These textbooks are listed in the appendix.

13. Kenneth Clark, Landscape Into Art, new edition (New York: Harper and Row, 1976), pp. 173-76.

14. E.g. Norma Broude, ed., Seurat in Perspective (Englewood Cliffs, NJ: Prentice-Hall, 1978), p. 40; John Rewald, Georges Seurat (New York: Wittenborn and Company, 1943), pp. 32-36. 
15. Paul Hayes Tucker, Claude Monet (New Haven: Yale University Press, 1995), p. 134.

16. Paul Hayes Tucker, Monet in the '90s: The Series Paintings (Boston: Museum of Fine Arts , 1989).

17. Arthur Danto, Embodied Meanings (New York: Noonday Press, 1994), pp. 85-87.

18. John Coplans, Provocations (London: London Projects, 1996), pp. 90-91.

19. Françoise Gilot and Carlton Lake, Life With Picasso (New York: Doubleday, 1964), p. 75; John Richardson, A Life of Picasso, Vol. 2 (New York: Random House, 1996), p. 103.

20. Michael Leja, “The Monet Revival and New York School Abstraction,” in Paul Tucker, ed., Monet in the $20^{\text {th }}$ Century (New Haven: Yale University Press, 1998), pp. 98-108.

21. Alan Bowness, The Conditions of Success (New York: Thames and Hudson, 1989).

22. John Rewald, The History of Impressionism, revised ed. (New York: Museum of Modern Art, 1961), pp. 310-12, 591.

23. Ibid., pp. 211-12.

24. Camille Pissarro, Letters to His Son Lucien (New York: Da Capo Press, 1995), p. 30.

25. Ralph Shikes and Paula Harper, Pissarro (New York: Horizon Press, 1980), pp. 209-12.

26. Pissarro, Letters, p. 64.

27. Ibid., pp. 64, 73-74.

28. Ibid., p. 93.

29. Ibid., p. 132.

30. Ibid., p. 135.

31. Ibid., p. 158.

32. Rewald, Georges Seurat, p. 68.

33. Lawrence Hanson, Renoir (New York: Dodd, Mead and Company, 1968), p. 201.

34. Ibid., p. 210.

35. Ibid., p. 211. 
36. Ibid., p. 220; also see Robert Herbert, Nature's Workshop (New Haven: Yale University Press, 2000), p. 66.

37. Nicholas Wadley, ed., Renoir (New York: Hugh Lauter Levin Associates, 1987), p. 273.

38. Ambroise Vollard, Renoir (New York: Alfred A. Knopf, 1925), p. 216. On the importance of new pigments in the Impressionists’ palette, see David Bomford, et. al., Art in the Making: Impressionism (New Haven: Yale University Press, 1990), pp. 51-75.

39. Michael Doran, ed., Conversations with Cézanne (Berkeley: University of California Press, 2001), p. 22.

40. Roger Fry, Cézanne (Chicago: University of Chicago Press, 1989), pp. 33-36.

41. John Rewald, Paul Cézanne (New York: Simon and Schuster, 1948), p. 176.

42. Pissarro, Letters, pp. 275-77.

43. Doran, Conversations with Cézanne, p. 65.

44. Paul Cézanne, Letters (New York: Da Capo Press, 1995), p. 303.

45. Ibid., p. 317.

46. E.g. see Erle Loran, Cézanne's Composition (Berkeley: University of California Press, 2006), Chap. 9.

47. Cézanne, Letters, p. 327.

48. Richard Kendall, ed., Monet by Himself (New York: Knickerbocker Press, 1999), p. 126.

49. Ibid., p. 172.

50. Ibid., p. 178.

51. Cézanne, Letters, p. 302.

52. Ibid., pp. 293-94.

53. Kendall, Monet by Himself, p. 172.

54. Ibid., p. 265.

55. Cézanne, Letters, p. 313.

56. Ibid., p. 329. 
57. Ibid., p. 231.

58. Kendall, Monet by Himself , p. 251.

59. Cézanne, Letters, p. 298.

60. Roger Shattuck, The Innocent Eye (Boston: MFA Publications, 2003), p. 237.

61. Kendall, Monet by Himself , p. 20.

62. Ibid., p. 178.

63. Doran, Conversations with Cézanne, p. 39.

64. Ibid., pp. 324, 335.

65. Kendall, Monet by Himself , p. 265.

66. Cézanne, Letters, p. 280.

67. Ibid., p. 299.

68. Ibid., p. 306.

69. Ibid., p. 315.

70. Charles Stuckey, ed., Monet (New York: Park Lane, 1986), p. 267.

71. Richard Brettell and Christopher Lloyd, A Catalogue of the Drawings by Camille Pissarro in the Ashmolean Museum, Oxford (Oxford: Clarendon Press, 1980), pp. 43-50; John House, Impressionism (New Haven: Yale University Press, 2004), pp. 203-05; Herbert, Nature's Workshop, p. 66; Christopher Lloyd, ed., Studies on Camille Pissarro (London: Routlege and Kegan Paul, 1986), pp. 20-25.

72. John House, Monet (New Haven: Yale University Press, 1986), pp. 45, 230; Rewald, Cézanne, p. 203.

73. George Heard Hamilton, Claude Monet's Paintings of Rouen Cathedral (London: Oxford University Press, 1960), pp. 26-27.

74. Stuckey, Monet, p. 372.

75. Cézanne, Letters, p. 330.

76. Robert Herbert, “The Decorative and the Natural in Monet's Cathedrals,” in John Rewald and Frances Weitzenhoffer, eds., Aspects of Monet (New York: Harry N. Abrams, 1984), p. 174. 
77. Theodore Reff, "Painting and Theory in the Final Decade,” in William Rubin, ed., Cézanne: The Late Work (New York: Museum of Modern Art, 1977), p. 13; Leo Steinberg, Other Criteria (London: Oxford University Press, 1972), p. 236.

78. Bourgeois, Destruction of the Father, p. 261. 
Table 1: Total Illustrations, Five Artists

\begin{tabular}{|l|c|c|c|}
\hline Artist & Year of birth & Year of death & Illustrations \\
\hline \hline Paul Cézanne & 1839 & 1906 & 175 \\
\hline Edgar Degas & 1834 & 1917 & 145 \\
\hline Claude Monet & 1840 & 1926 & 166 \\
\hline Camille Pissarro & 1830 & 1903 & 55 \\
\hline Pierre-Auguste Renoir & 1841 & 1919 & 96 \\
\hline
\end{tabular}

Source: See text and appendix. 
Table 2: Distributions of Illustrations by Ages at Execution of Works, Five Artists

\begin{tabular}{|l|c|c|c|c|c|c|c|c|}
\hline Artist & $20-9$ & $30-9$ & $40-9$ & $50-9$ & $60-9$ & $70-9$ & $80-9$ & Total \\
\hline \hline Cézanne & 5 & 30 & 39 & 40 & 61 & - & - & 175 \\
\hline Degas & 7 & 26 & 68 & 33 & 11 & 0 & 0 & 145 \\
\hline Monet & 37 & 65 & 4 & 28 & 9 & 3 & 20 & 166 \\
\hline Pissarro & 0 & 5 & 26 & 12 & 11 & 1 & - & 55 \\
\hline Renoir & 15 & 37 & 29 & 4 & 3 & 8 & - & 96 \\
\hline
\end{tabular}

Source: See text and appendix. 
Appendix. The books surveyed for this study are listed here. In two cases, books that were included in a series were treated as a single book.

Adams, Laurie, Art Across Time, third ed. Boston: McGraw Hill, 2006.

Arnason, H. H., History of Modern Art, fifth ed. Upper Saddle River, NJ: Prentice Hall, 2004.

Bocola, Sandro, The Art of Modernism. Munich: Prestel, 1999.

Bowness, Alan, Modern European Art. London: Thames and Hudson, 1972.

Brettell, Richard, Modern Art, 1851-1929. Oxford: Oxford University Press, 1999.

Britt, David., ed., Modern Art. New York: Thames and Hudson, 1999.

Canaday, John, Mainstreams of Modern Art, second ed. Ft. Worth: Harcourt Brace Jovanovich, 1981.

Cornell, Sara, Art. Englewood Cliffs, NJ: Prentice-Hall, 1983.

Croix, Horst de la, and Richard Tansey, Gardner's Art Through the Ages, sixth ed. New York: Harcourt Brace Jovanovich, 1975.

Cumming, Robert, Art. New York: DK Publishing, 2005.

Davies, Penelope, et. al., Janson's History of Art, seventh ed. Upper Saddle River, NJ: Pearson, 2007.

Dawtrey, Liz, et. al., Investigating Modern Art. New Haven: Yale University Press, 1996.

Dempsey, Amy, Art in the Modern Era. New York: Abrams, 2002.

Fleming, William, Arts and Ideas, ninth ed. Ft. Worth: Harcourt Brace, 1995.

Frascina, Francis, et. al., Modernity and Modernism. New Haven: Yale University Press, 1993.

book in same series: Charles Harrison, Francis Frascina, and Gill

Perry, Primitivism, Cubism, Abstraction. New Haven: Yale

University Press, 1993.

Freeman, Julian, Art. New York: Watson-Guptill, 1998.

Gebhardt, Volker, The History of Art. New York: Barron’s, 1998.

Gilbert, Rita, Living with Art, fifth ed. Boston: McGraw Hill, 1998. 
Gombrich, E. H., The History of Art, sixteenth ed. London: Phaidon Press, 1995.

Hamilton, George Heard, 19th and 20th Century Art. New York: Abrams, 1970.

Harrison, Charles, Modernism. Cambridge: Cambridge University Press, 1997.

Hartt, Frederick, Art, third ed. Englewood Cliffs, NJ: Prentice-Hall, 1989.

Honour, Hugh, and John Fleming, The Visual Arts, sixth ed. New York: Abrams, 2002.

Hughes, Robert, The Shock of the New. New York: Alfred A. Knopf, 1991.

Hunter, Sam; John Jacobus, and Daniel Wheeler, Modern Art, third ed. New York: Vendome Press, 2003.

Janson, H. W., History of Art, fifth ed. Englewood Cliffs, NJ: Prentice Hall, 1995.

Johnson, Paul, Art. New York: Harper Collins, 2003.

Kemp, Martin, ed., The Oxford History of Western Art. Oxford: Oxford University Press, 2000.

Novotny, Fritz, Painting and Sculpture in Europe, 1780 to 1880. Harmondsworth: Penguin, 1972.

book in some series: Hamilton, George Heard, Painting and

Sculpture in Europe, 1880 - 1940. Harmondsworth: Penguin, 1972.

Preble, Duane, and Sarah Preble, Artforms, fourth ed. New York: Harper Collins, 1989.

Richter, Klaus, Art. Munich: Prestel, 2001.

Ruskin, Ariane, History in Art. New York: Franklin Watts, 1974.

Russell, John, The Meanings of Modern Art. New York: Harper and Row, 1981.

Spencer, Harold, The Image Maker. New York: Charles Scribner’s Sons, 1975.

Sporre, Dennis, The Arts. Englewood Cliffs, NJ: Prentice-Hall, 1984.

Stokstad, Marilyn, Art History. New York: Abrams, 1995.

Strickland, Carol, The Annotated Mona Lisa. Kansas City: Andrews and McMeel, 1992.

Sprocatti, Sandro, A Guide to Art. New York: Abrams, 1992.

Thuillier, Jacques, History of Art. Paris: Flammarion, 2003. 
Varnedoe, Kirk, A Fine Disregard. New York: Abrams, 1990.

Walther, Ingo, ed., Masterpieces of Western Art. Cologne: Taschen, 2005.

Wilkins, David; Bernard Schultz, and Katheryn Linduff, Art Past, Art Present, third ed. New York: Abrams, 1997.

Wood, Michael; Bruce Cole, and Adelheid Gealt, Art of the Western World. New York: Simon and Schuster, 1989. 